\title{
Cytotoxicity evaluation of a new ozonized olive oil
}

\author{
Marco Colombo ${ }^{1}$, Matteo Ceci $^{1}$, Eleonora Felisa ${ }^{1}$, Claudio Poggio ${ }^{1}$, Giampiero Pietrocola ${ }^{2}$
}

Correspondence: Dr. Claudio Poggio
Email: claudio.poggio@unipv.it

'Department of Clinical-Surgical, Diagnostic and Pediatric Sciences, Section of Dentistry, University of

Pavia, Pavia, Italy,

2Departement of Molecular Medicine, Unit of

Biochemistry, University of Pavia, Pavia, Italy

\section{ABSTRACT}

Objective: The cytocompatibility of a new ozonized olive oil toward immortalized human gingival fibroblasts (HGFs) was evaluated and compared with two common antimicrobial agents based on chlorhexidine digluconate (CHX). Materials and Methods: The cytocompatibility of the samples was tested on immortalized HGF-1 cells by 3-(4, 5-dimethyl thiazolyl-2)-2,5-diphenyltetrazolium bromide (MTT) assay. The cells were incubated for 2 or $24 \mathrm{~h}$ with increasing dilution of ozonized olive oil or CHX agents. The percentage of viable cells was calculated relative to control cells set to $100 \%$. Results: The ozonized olive oil is cytocompatible, and the viability values of the cells treated for 2 or $24 \mathrm{~h}$ with increasing concentrations of ozonized olive oil were significantly higher $(P<0.01)$ compared with the values obtained using CHX. Conclusions: The present data demonstrate that due to its cytocompatibility, the new ozonized olive oil could be considered an alternative antibacterial agent.

Key words: 3-(4, 5-dimethyl thiazolyl-2)-2,5-diphenyltetrazolium bromide test, cytotoxicity, gingival fibroblast, ozonized olive oil

\section{INTRODUCTION}

The use and approval of ozone therapy among dental and medical professionals have been increasing during recent years. It has been suggested for the cure of more than 250 different pathologies. ${ }^{[1]}$ This is due to the characteristics of ozone including its high oxidative power, stimulation of blood circulation and immune response, its analgesic properties, and its strong antimicrobial activity against viruses, bacteria, fungi, and protozoa. ${ }^{[2]}$

Ozone is used in many dental therapies including tissue regeneration and postsurgery healing, ${ }^{[3]}$ tooth surface remineralization and treatment of early dental caries, ${ }^{[4,5]}$ root canal disinfection, ${ }^{[6]}$ periodontal pocket therapy, ${ }^{[7]}$ teeth whitening and management of tooth sensitivity, ${ }^{[8,9]}$ and pain control and temporomandibular joint treatment. ${ }^{[10]}$

\begin{tabular}{|l|l|}
\hline \multicolumn{2}{|c|}{ Access this article online } \\
\hline Quick Response Code: \\
\hline
\end{tabular}

Plaque biofilm is the main cause of both caries and periodontal disease. Ozone has been demonstrated to be useful to control oral infectious microorganisms in dental plaque. ${ }^{[11]}$ In dental treatments, ozone can be applied in three different forms: ozone gas, ozonated water, and ozonated oil..$^{[1]}$ Ozonated water strongly inhibited the accumulation of experimental dental plaque. ${ }^{[12]}$ Similarly, ozonated oils such as ozonated sunflower oil, olive oil, and groundnut oil were capable of inducing the reduction of many oral microorganisms. ${ }^{[13]}$

Ozone exerts its own antimicrobial action through the synergistic action of damaging the cytoplasmic membrane of cells and of inducing the modification of

This is an open access journal, and articles are distributed under the terms of the Creative Commons Attribution-NonCommercial-ShareAlike 4.0 License, which allows others to remix, tweak, and build upon the work non-commercially, as long as appropriate credit is given and the new creations are licensed under the identical terms.

For reprints contact: reprints@medknow.com

How to cite this article: Colombo M, Ceci M, Felisa E, Poggio C, Pietrocola G. Cytotoxicity evaluation of a new ozonized olive oil. Eur J Dent 2018;12:585-9.

DOI: $10.4103 /$ ejd.ejd_422_18 
intracellular contents because of secondary oxidants effects. ${ }^{[14]}$ This action is nonspecific and selective to microbial cells; however, the activity of ozone on human cells has been investigated considering the importance of complete biocompatibility of ozone in its use in dental practice. ${ }^{[15]}$

O-zone gel (Alnitec, Cremosano, CR, Italy) is a new ozonated olive oil with bactericidal and fungicidal properties whose use is suggested for the periodontal treatments of both gingivitis and periodontitis affections and for the root canal disinfection during endodontic therapies.

The aim of the present study is to evaluate the biocompatibility of this new ozonized olive oil on immortalized human gingival fibroblasts (HGFs) and to compare it with two common antimicrobial agents based on chlorhexidine digluconate (CHX). The null hypothesis of the study was that the ozonated oil did not demonstrate cytotoxic effects; therefore, there was no difference between the cytotoxic capability of the three different antimicrobial agents tested.

\section{MATERIALS AND METHODS}

A new ozonized olive oil was selected for this study: O-zone gel (Alnitec, Cremosano, CR, Italy). Cytocompatibility was compared with two common antimicrobial agents based on CHX: Corsodyl Dental $\mathrm{Gel}^{\circledR}$ (GlaxoSmithKline, Brentford, Middlesex, UK) and Plak Gel ${ }^{\circledR}$ (Polifarma, Rome, Italy).

\section{Cell culture}

Immortalized HGF-1 (ATCC CRL-2014) was obtained from the American Type Culture Collection and cultured in high-glucose Dulbecco's modified Eagle's medium (DMEM; Sigma-Aldrich, St. Louis, MO, USA) supplemented with $4 \mathrm{mML}$-glutamine (Sigma-Aldrich), $1 \%$ penicillin, streptomycin (Sigma-Aldrich), and $10 \%$ (vol/vol) heat-inactivated fetal bovine serum (FBS; Sigma-Aldrich). Cells were incubated at $37^{\circ} \mathrm{C}$ in $5 \% \mathrm{CO}_{2}$ in $\mathrm{T} 75$ flasks to approximately $95 \%$ confluence, liberated with trypsin-EDTA (0.05\%; Sigma-Aldrich), and plated as reported below.

\section{Cytocompatibility test}

Cells were plated at $1 \times 10^{4}$ into 96 -well plates (Corning) and allowed to attach for $24 \mathrm{~h}$ at $37^{\circ} \mathrm{C}$. The following day, the ozonized olive oil and the $\mathrm{CHX}$ agents namely Corsodyl Dental Gel ${ }^{\circledR}$ or Plak Gel ${ }^{\circledR}$ were diluted 1:10 for 4 times in DMEM. The cell medium was removed from the well, and $100 \mu \mathrm{L}$ of each diluted test agent was applied to the cell monolayers. As negative control, fresh medium was used. After 2 or 24 h of incubation at $37^{\circ} \mathrm{C}$, the cell medium was pipetted off from each well and HGFs viability determined using the 3-(4,5-dimethyl thiazolyl-2)-2,5-diphenyltetrazolium bromide (MTT) assay. $100 \mu \mathrm{L}$ of MTT solution (Sigma-Aldrich) in RPMI-1640 without phenol red (Sigma-Aldrich) $(5 \mathrm{mg} / \mathrm{mL}$ ) was added to each well, and the monolayers were incubated for $4 \mathrm{~h}$ at $37^{\circ} \mathrm{C}$. Then, the supernatant was removed, and the resulting formazan was dissolved by adding $100 \mu \mathrm{L}$ dimethyl sulfoxide (Sigma-Aldrich) to each well. The optical density of formazan dye was read at $545 \mathrm{~nm}$ against $620 \mathrm{~nm}$ as background by ELISA reader (Bio-Rad, Hercules, CA, USA). The percentage of viable cells in each well was calculated relative to control cells set to $100 \%$. Cytotoxicity responses were rated as severe $(30 \%)$, moderate $(30 \%-60 \%)$, mild $(60 \%-90 \%)$, or noncytotoxic $(>90 \%) \cdot{ }^{[16]}$

\section{Statistical analysis}

Cell viability data were analyzed by one-way ANOVA, followed by Bonferroni's post hoc tests. Analyses were performed using Prism 4.0 (GraphPad Software Inc., La Jolla, CA, USA). Two-tailed $P=0.05$ was considered statistically significant.

\section{RESULTS}

To evaluate cell viability in the presence of increasing dilution of the three gingival gels tested, an MTT assay was performed. The results are shown in Tables 1 and 2 and collectively represented in Figure 1.

No cytotoxic effect was measured by incubating the cell monolayers for $2 \mathrm{~h}$ with all the dilutions tested of the ozonized olive oil. The differences in cell viability were statistically significantly lower $(P<0.01)$ when the cell monolayers were incubated with increasing dilution of both CHX agents: Corsodyl Dental Gel ${ }^{\circledR}$ or Plak Gel ${ }^{\circledR}$.

\begin{tabular}{|c|c|c|c|c|}
\hline \multirow[t]{2}{*}{ Samples } & \multicolumn{4}{|c|}{$\begin{array}{c}2 \mathrm{~h} \\
\text { Dilutions }\end{array}$} \\
\hline & $1: 10$ & $1: 10^{2}$ & $1: 10^{3}$ & $1: 10^{4}$ \\
\hline $\bar{A}$ & $\begin{array}{l}124.20 \pm 10.17 \\
\text { Noncytotoxic }\end{array}$ & $\begin{array}{l}124.02 \pm 13.25 \\
\text { Noncytotoxic }\end{array}$ & $\begin{array}{l}132.96 \pm 7.60 \\
\text { Noncytotoxic }\end{array}$ & $\begin{array}{l}133.09 \pm 7.57 \\
\text { Noncytotoxic }\end{array}$ \\
\hline B & $\begin{array}{l}26.24 \pm 8.16 \\
\text { Severe }\end{array}$ & $\begin{array}{l}31.14 \pm 3.97 \\
\text { Moderate }\end{array}$ & $\begin{array}{l}30.29 \pm 4.47 \\
\text { Moderate }\end{array}$ & $\begin{array}{c}31.81 \pm 3.13 \\
\text { Moderate }\end{array}$ \\
\hline C & $\begin{array}{l}28.87 \pm 5.19 \\
\text { Severe }\end{array}$ & $\begin{array}{l}30.35 \pm 3.65 \\
\text { Moderate }\end{array}$ & $\begin{array}{c}35.46 \pm 7.76 \\
\text { Moderate }\end{array}$ & $\begin{array}{c}44.08 \pm 15.92 \\
\text { Moderate }\end{array}$ \\
\hline
\end{tabular}




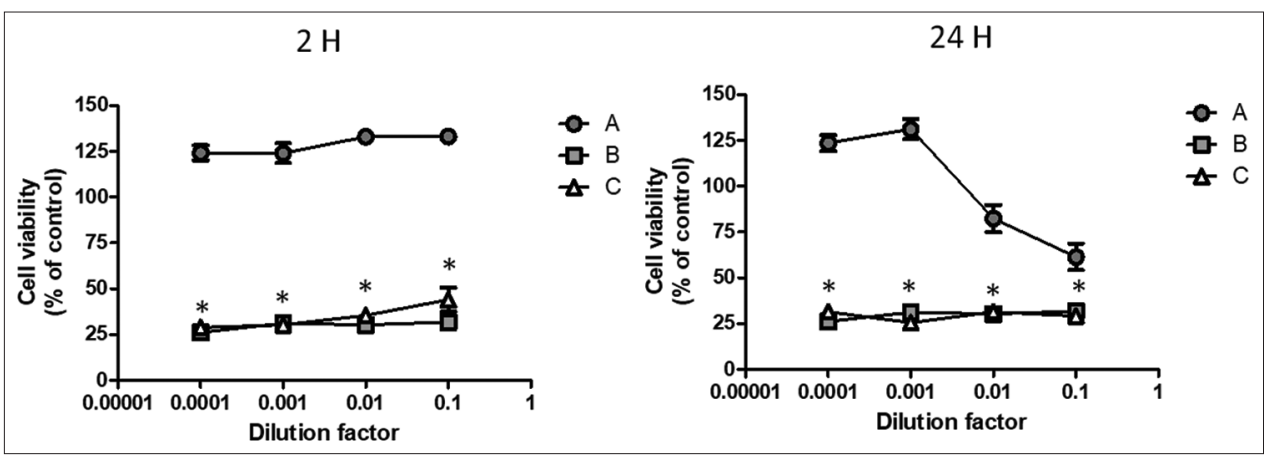

Figure 1: Time-dependent effects of different gingival gels on viability of human gingival fibroblast. Confluent human gingival fibroblast was treated for 2 or $24 \mathrm{~h}$ with 10-fold dilution of different gingival gels (A: O-zone gel; B: Corsodyl Dental Gel ${ }^{\circledR}$; C: Plak Gel ${ }^{\circledR}$ ). The cell viability was measured by the 3-(4, 5-dimethyl thiazolyl-2)-2,5-diphenyltetrazolium bromide assay. Statistically significant $(P<0.05$; Student's $t$-test) differences in values compared with the control value (untreated) are indicated by an asterisk. Bars and error bars represent the means and \pm standard deviation from three independent determinations performed in triplicate

\begin{tabular}{|c|c|c|c|c|}
\hline \multirow[t]{2}{*}{ Samples } & \multicolumn{4}{|c|}{$\begin{array}{c}24 \mathrm{~h} \\
\text { Dilutions }\end{array}$} \\
\hline & $1: 10$ & $1: 10^{2}$ & $1: 10^{3}$ & $1: 10^{4}$ \\
\hline$A$ & $\begin{array}{c}61.39 \pm 17.72 \\
\text { Moderate }\end{array}$ & $\begin{array}{c}82.38 \pm 18.14 \\
\text { Mild }\end{array}$ & $\begin{array}{l}131.16 \pm 13.48 \\
\text { Noncytotoxic }\end{array}$ & $\begin{array}{l}123.55 \pm 10.72 \\
\text { Noncytotoxic }\end{array}$ \\
\hline$B$ & $\begin{array}{l}28.12 \pm 8.16 \\
\text { Severe }\end{array}$ & $\begin{array}{c}32.16 \pm 3.79 \\
\text { Moderate }\end{array}$ & $\begin{array}{l}30.92 \pm 4.74 \\
\text { Moderate }\end{array}$ & $\begin{array}{l}31.18 \pm 3.31 \\
\text { Moderate }\end{array}$ \\
\hline C & $\begin{array}{c}29.17 \pm 6.83 \\
\text { Severe }\end{array}$ & $\begin{array}{c}31.44 \pm 3.68 \\
\text { Moderate }\end{array}$ & $\begin{array}{l}30.57 \pm 7.75 \\
\text { Moderate }\end{array}$ & $\begin{array}{c}30.44 \pm 3.31 \\
\text { Moderate }\end{array}$ \\
\hline
\end{tabular}

A: O-zone gel, B: Corsodyl Dental Gel ${ }^{\circledR}$, C: $^{\text {Plak Gel }}{ }^{\circledR}$

Cytotoxicity responses were rated as severe $(30 \%)$, moderate

$(30 \%-60 \%)$, mild $(60 \%-90 \%)$ or noncytotoxic $(>90 \%)$

Moreover, their cell viability (severe/moderate) data were also statistically significantly lower compared to the control $(P<0.01)$ (culture medium only).

No cytotoxic effect was measured by incubating $24 \mathrm{~h}$ the cell monolayers with the ozonized olive oil diluted $10^{3}$ and $10^{4}$ times. Instead, the cytotoxic effect was mild using the gel diluted $10^{2}$ times. The cytotoxic effect was moderate using the gel diluted 10 times and the differences in cell viability were statistically significant compared to the control $(P<0.05)$. The differences in cell viability remained severe/moderate for all the gel dilutions tested and statistically significantly lower $(P<0.01)$ compared to both the cell monolayers treated with the ozonized olive oil and the control.

\section{DISCUSSION}

The production of ozone $\left(\mathrm{O}_{3}\right)$ is naturally obtained by the photodissociation of molecular oxygen $\left(\mathrm{O}_{2}\right)$ into activated oxygen atoms, which then react with further oxygen molecules. ${ }^{[1]}$ This transient radical anion rapidly becomes protonated, generating hydrogen trioxide $\left(\mathrm{HO}_{3}\right)$, which, in turn, decomposes to an even more powerful oxidant, the hydroxyl radical $(\mathrm{OH}) \cdot{ }^{[1]}$

For the treatment of infections, the use of ozone became an inherent element in such fields as surgery, dermatology, cosmetics, and dentistry during the last few years. ${ }^{[17]}$

Ozone therapy is based on various useful effects. Ozone is not only an antimicrobial agent, but it can also enhance blood circulation and immune response. Ozone can modulate cellular and humoral immune system, by the proliferation of immunocompetent cells and synthesis of immunoglobulins. It can stimulate the phagocytosis process, activate the macrophages, and increase the sensitivity of microorganisms to macrophages. ${ }^{[18]}$

The European Cooperation of Medical Ozone Societies forbids the direct intravenous injections of ozone/ oxygen gas due to the risk of air embolism. ${ }^{[19]}$ There are three basic forms of ozone application: ozone gas, ozonated water, and ozonated oil. ${ }^{[1]}$ In this study, the new ozonized olive oil O-zone gel (Alnitec), suggested as a coadjutant in periodontal and endodontic treatments, was tested.

The oxidative power of ozone is 1.5 times greater than that of chloride when used as an antimicrobial agent. ${ }^{[1]}$ This effect of oxidation gives to ozone its most important property: its bactericidal, virucidal, and fungicidal activity. ${ }^{[12]}$ According to microbiological studies, ozone is capable of killing all the known types of Gram-positive and Gram-negative bacteria, including the Pseudomonas aeruginosa and Escherichia coli, both of which are extremely resistant to antibiotics. ${ }^{[1]}$ This antimicrobial capacity is the result of ozone effects on cells such as damaging the cytoplasmic membrane due 
to ozonolysis of dual bonds and inducing changes of cytoplasmic contents. This action seems not to damage human body cells; the reason attributed to this is antioxidant ability of mammalian cells. ${ }^{[20]}$

In our study, the cytocompatibility of ozone (and in this case of an ozonated oil) toward human cells was tested. The cytotoxicity of the different antimicrobial agents has been investigated, using the MTT assay. The MTT test is a standard colorimetric assay for measuring the activity of enzymes that reduce the MTT to formazan (a salt blue) in the mitochondria, giving the substance a blue/purple color. This technique has been widely used to characterize the cytocompatibility of various dental materials. ${ }^{[21]}$

The null hypothesis of this study was partially rejected. In fact, the new ozonated oil did not show any cytotoxic effects; however, differences between the cytotoxic capabilities of the three different antimicrobial agents tested were demonstrated.

No cytotoxic activity of the ozonated olive oil was revealed by incubating the cell monolayers for $2 \mathrm{~h}$ with all the dilutions tested. However, all the increasing dilutions of both CHX agents demonstrated moderate or severe cytotoxic responses after $2 \mathrm{~h}$ of testing. After $24 \mathrm{~h}$ of incubation, no cytotoxic effect was measured for the ozonized olive oil diluted $10^{3}$ and $10^{4}$ times. However, a mild cytotoxicity was registered using the ozone oil diluted $10^{2}$ and 10 times. The cell viability of both the CHX agents tested remained severe/moderate for all the dilutions even after $24 \mathrm{~h}$ of experimentation.

Recent studies have assessed the antimicrobial capability of ozonated oils against different microbiological strains. Gram-negative bacteria, such as Porphyromonas endodontalis and Porphyromonas gingivalis, proved to be more sensitive to ozone oil than Gram-positive streptococci. ${ }^{[22]}$ Huth et al. compared the bactericidal effects of ozone oil against periodontal microorganisms; ozone gel showed more effectiveness

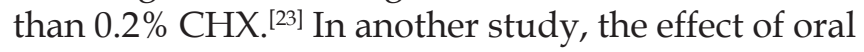
irrigations with ozonated oil, $0.2 \% \mathrm{CHX}$, or $10 \%$ povidone-iodine in patients with chronic periodontal disease was evaluated, stating that the use of ozone can serve as potent atraumatic alternative to treat periodontal pockets nonsurgically. ${ }^{[24]}$ In root canal therapy, ozonated oils proved to be more efficient than the conventional irrigation by sodium hypochlorite and sodium peroxide combination. ${ }^{[13]}$

However, few studies have evaluated the cytocompatibility of ozonated oils, comparing it with that of other antimicrobial agents used in periodontal or endodontic therapies. In this study, the ozone oil tested prove to be a biocompatible agent; contrariwise, the CHX-based gels showed higher degrees of cytotoxicity both after 2 and $24 \mathrm{~h}$ of incubation. Only after $24 \mathrm{~h}$, a fair cytotoxic effect of O-zone gel diluted $10^{2}$ and 10 times was registered. Anyhow, we suppose that this value of cytotoxicity of ozone gel after $24 \mathrm{~h}$ may be considered irrelevant because the product applied to the gingiva tends to dilute progressively over time, and after $24 \mathrm{~h}$, it has abundantly diluted with saliva.

The findings of our study are in accordance with recent studies. Nagayoshi et al. compared the biological properties of an ozone oil with that of sodium hypochlorite, thus demonstrating that the metabolic activity of human fibroblasts was high when treated with ozonated oil. ${ }^{[25]}$ Other authors showed less cytotoxic effect of ozone, as a potential antiseptic agent, if compared to other antimicrobials such as CHX, sodium hypochlorite, or hydrogen peroxide. ${ }^{[26]}$ Therefore, ozone gel fulfills optimal cell biological characteristics in terms of biocompatibility for oral application..$^{[15]}$

\section{CONCLUSIONS}

Within the limitations of this in vitro study, the ozonated olive oil tested proved to be a biocompatible agent, while the chlorhexidine-based gels demonstrated higher cytotoxic effects. Due to its cytocompatibility, ozonated olive oil may be considered an alternative to conventional antimicrobials agents in periodontal or endodontic treatments.

\section{Financial support and sponsorship Nil.}

\section{Conflicts of interest}

There are no conflicts of interest.

\section{REFERENCES}

1. Nogales CG, Ferrari PH, Kantorovich EO, Lage-Marques JL. Ozone therapy in medicine and dentistry. J Contemp Dent Pract 2008;9:75-84.

2. Bocci VA. Scientific and medical aspects of ozone therapy. State of the art. Arch Med Res 2006;37:425-35.

3. Taşdemir Z, Alkan BA, Albayrak H. Effects of ozone therapy on the early healing period of deepithelialized gingival grafts: A randomized placebo-controlled clinical trial. J Periodontol 2016;87:663-71.

4. Gürsoy H, Cakar G, Ipçi SD, Kuru B, Yilmaz S. In vitro evaluation of the effects of different treatment procedures on dentine tubules. Photomed Laser Surg 2012;30:695-8.

5. Lynch E. Evidence-based caries reversal using ozone. J Esthet Restor Dent 2008;20:218-22.

6. Lynch E. Evidence-based efficacy of ozone for root canal irrigation. 
J Esthet Restor Dent 2008;20:287-93.

7. Al Habashneh R, Alsalman W, Khader Y. Ozone as an adjunct to conventional nonsurgical therapy in chronic periodontitis: A randomized controlled clinical trial. J Periodontal Res 2015;50:37-43.

8. Al-Omiri MK, Abul Hassan RS, AlZarea BK, Lynch E. Improved tooth bleaching combining ozone and hydrogen peroxide - A blinded study. J Dent 2016;46:30-5.

9. Raafat Abdelaziz R, Mosallam RS, Yousry MM. Tubular occlusion of simulated hypersensitive dentin by the combined use of ozone and desensitizing agents. Acta Odontol Scand 2011;69:395-400.

10. Kazancioglu HO, Kurklu E, Ezirganli S. Effects of ozone therapy on pain, swelling, and trismus following third molar surgery. Int J Oral Maxillofac Surg 2014;43:644-8.

11. Saini R. Ozone therapy in dentistry: A strategic review. J Nat Sci Biol Med 2011;2:151-3.

12. Garg R, Tandon S. Ozone: A new face of dentistry. Int J Dent Sci 2009;7:2-10.

13. Estrela C, Estrela CR, Decurcio DA, Hollanda AC, Silva JA. Antimicrobial efficacy of ozonated water, gaseous ozone, sodium hypochlorite and chlorhexidine in infected human root canals. Int Endod J 2007;40:85-93.

14. Stübinger S, Sader R, Filippi A. The use of ozone in dentistry and maxillofacial surgery: A review. Quintessence Int 2006;37:353-9.

15. Azarpazhooh A, Limeback $\mathrm{H}$. The application of ozone in dentistry: A systematic review of literature. J Dent 2008;36:104-16.

16. Poggio C, Riva P, Chiesa M, Colombo M, Pietrocola G. Comparative cytotoxicity evaluation of eight root canal sealers. J Clin Exp Dent 2017;9:e574-8.

17. Wilczyńska-Borawska M, Leszczyńska K, Nowosielski C, Stokowska W. Ozone in dentistry: Microbiological effects of gas action depending on the method and the time of application using the ozony tron device. Experimental study. Ann Acad Med Stetin 2011;57:99-103.

18. Babior BM, Takeuchi C, Ruedi J, Gutierrez A, Wentworth $P$ Jr. Investigating antibody-catalyzed ozone generation by human neutrophils. Proc Natl Acad Sci U S A 2003;100:3031-4.

19. International Scientific Communications Ozonether. Ozone Therapy and its Scientific Foundations. Madrid (Spain): ISCO3; 2012.

20. Thanomsub B, Anupunpisit V, Chanphetch S, Watcharachaipong T, Poonkhum R, Srisukonth C. Effects of ozone treatment on cell growth and ultrastructural changes in bacteria. J Gen Appl Microbiol 2002;48:193-9.

21. Poggio C, Ceci M, Beltrami R, Dagna A, Colombo M, Chiesa M. Biocompatibility of a new pulp capping cement. Ann Stomatol (Roma) 2014;5:69-76.

22. Nagayoshi M, Kitamura C, Fukuizumi T, Nishihara T, Terashita M. Antimicrobial effect of ozonated water on bacteria invading dentinal tubules. J Endod 2004;30:778-81.

23. Huth KC, Quirling M, Maier S, Kamereck K, Alkhayer M, Paschos E, et al. Effectiveness of ozone against endodontopathogenic microorganisms in a root canal biofilm model. Int Endod J 2009;42:3-13.

24. Dodwad V, Gupta S, Kumar K, Sethi M, Masamatti S. Changing paradigm in pocket therapy-ozone versus conventional irrigation. Int J Public Health Dent 2011;2:7-12.

25. Nagayoshi M, Fukuizumi T, Kitamura C, Yano J, Terashita M, Nishihara T. Efficacy of ozone on survival and permeability of oral microorganisms. Oral Microbiol Immunol 2004;19:240-6.

26. Naik SV, Rajeshwari K, Kohli S, Zohabhasan S, Bhatia S. Ozone - A biological therapy in dentistry-reality or myth? Open Dent J 2016;10:196-206. 